\title{
Preliminary phytochemical and antileishmanial studies of the ethanolic extracts of Pterodon pudescens
}

\begin{abstract}
ARRAIS-SILVA, W.W.1*; NUNES, P.S.G. ${ }^{2}$; CARVALHO, J.D.'; BRUNE, M.W.'; ARRAIS-LIMA, C.1; BATALINI C 2. 'Laboratório de Parasitos e Vetores - Campus Universitário do Araguaia, Universidade Federal de Mato Grosso, CEP 78698-000, Caixa Postal 232, Barra do Garças-MT, Brasil *Correspong author: arrais-silva@ufmt.br; ${ }^{2}$ Núcleo de Investigação Químico Epideniofarmacológico do Médio Araguaia - Campus Universitário do Araguaia, Universidade Federal de Mato Grosso, CEP 78698-000, Pontal do Araguaia-MT, Brasil
\end{abstract}

\begin{abstract}
Pentavalent antimonials are the first choice for the treatment of human leishmaniasis. However in rural areas the traditional plants may be preferred for the treatment of lesions. In recent years a number of papers are published related to the natural products especially plant derivative with infectious diseases. The present work was undertaken to evaluate the antileishmanial activity of Pterodon pubescens which is a native tree widely distributed over the central region of Brazil and used in folk medicine as wine infusions to treat inflammatory disease. The phytochemical screening and the biological essay of ethanolic extract of Pterodon pudescens (PPE) leaves at the concentrations of $150,300,450,600 \mu \mathrm{g} / \mathrm{ml}$ were tested in vitro in Leishmania amazonensis-infected macrophages to support its traditional medicinal use as a leishmaniasis remedy. Phytochemical screening of PPE has shown the presence of catechemical tannins, steroids, triterpenoids and flavonoids. The biological test suggests that PPE were found to control parasite burden of cell cultures in dose-dependent manner. These findings highlight the fact that the apparent potency of Pterodon pudescens compounds, together with their widely distribution over Latin America and Brazil, may represent a promising antileishmanial agent.
\end{abstract}

Keywords: Pterodon pubscens, Leishmania amazonensis, Plant extract

RESUMO: Estudos preliminares sobre a fitoquimica e a atividade anti-leishmania de extratos etanólicos de Pterodon pudescens. Antimoniais pentavalentes são a primeira escolha para o tratamento das leishmanioses humanas. No entanto, no interior brasileiro plantas tradicionais são usadas para o tratamento dessas lesões. De fato, recentes trabalhos tem relatado o potencial terapêutico de produtos naturais, especialmente derivados de plantas. Neste estudo avaliamos a atividade leishmanicida de Pterodon pubescens, uma árvore nativa, distribuída pela região central brasileira e usada em infusões para tratamento de inflamações. Foi realizada a análise fitoquímica e o ensaio in vitro em macrófagos infectados com Leishmania amazonensis em concentrações de 150, 300,450, $600 \mu \mathrm{g} / \mathrm{ml}$ do extrato etanólico de folhas de Pterodon pudescens (PPE) para comprovar o uso tradicional desta planta como terapia para as leishmanioses. Os testes fitoquímicos indicaram a presença de taninos catequímicos, flavonas, esteroides, triterpenoides, flavonoides e xantonas. Os ensaios biológicos revelaram que o PPE foi capaz de controlar a carga parasitária em macrófagos de maneira dose dependente. Estes resultados corroboram com o potencial terapêutico de compostos de Pterodon pudescens e, junto com sua ampla distribuição no Brasil, podem representar promissor agente leishmanicida.

Palavras-chaves: Pterodon pubscens, Leishmania amazonensis, Extrato de planta

\section{INTRODUCTION}

Leishmaniasis is a zoonotic complex of disease that displays widely different clinical manifestations in humans. The severity of the disease produced by several Leishmania species varies enormously, ranging from disfiguring scars and deformities caused by tegumentar leishmaniasis to death caused by viscerotropic species (Grimaldi \& Tesh, 1993). In addition, over the last years, leishmaniasis have impaired economic development and placed enormous burdens on Leishmaniaafflicted developing countries (2 million new cases are reported each year), and consequently

Recebido para publicação em 13/09/2011

Aceito para publicação em 31/03/2014 
continue to be an enormous global health challenge (Handman et al., 2008).

The first line of therapy for all forms of the disease is pentavalent antimonial, sodium stibogluconate, and meglumine antimoniate glucantime (Berman, 2006). The polyene antibiotic amphotericin $B$ and diamidine pentamidine are second-line drugs, and miltefosine, a lysophospholipid analog, is the most recent drug approved for leishmaniasis treatment (Berman, 2006; Mishra et al., 2007). However several works indicate that current therapies frequently fail to eradicate the parasite from infected tissues, while also presenting serious side effects (Berman, 2006).

Natural product scaffolds have been the basis of the majority of current anti parasitic medicines. Molecules such as quinine, lapachol and artemisinin were originally isolated from herbal medicinal products. The success of these drugs has broadened the search for natural plant products as a source of novel drugs for leishmaniasis (Ginsburg \& Deharo, 2011).

Pterodon pubescens (LeguminosaePapilionoideae) is a native tree widely distributed over the central region of Brazil, which is used in folk medicine as wine infusions to treat inflammatory disease (Lorenzi, 2009). Several works suggest immuno modulatory and anti-protozoa effect of plant component of Pterodon genera without side effects observed (Cardoso et al., 2008; Menna-Barreto et al., 2008; Dutra et al., 2009; Coelho et al., 2004). Recently, anti-tumoral effects have been shown for Pterodon pubescens extracts using in vitro model of leukemia (Pereira et al., 2011). Nevertheless, the effects of this extract on leishmaniasis remain unknown. In this study, experiments were designed to address whether in vitro treatment of primary murine macrophages with PPE can modulate the cellular response to Leishmania amazonensis infection.

\section{MATERIAL AND METHODS}

\section{Plant material and Pterodon pubescens Extract (PPE) preparation \\ Pterodon pubescens leaves were collected} around Pontal do Araguaia city, Mato Grosso State, Brazil in September 2008. The taxonomic identity was confirmed by Dr Maryland Sanchez Lacerda from the Federal University of Mato Grosso (UFMT). A voucher specimen was deposited in the central herbarium of the UFMT (No: 1950). The air-dried and powdered leaves of Pterodon pubescens were extracted with ethanol at room temperature during fifty days, in a dark condition. After complete ethanol evaporation, at $45^{\circ} \mathrm{C}$ in dry chamber, all of the extracts were prepared at $100 \%$ concentration $(\mathrm{g} / \mathrm{ml})$.

Phytochemical screening of extract

The major secondary metabolites classes such as Tannins, Phlobatannins, Saponins, Terpenoids, Steroids, Flavonoids, Alkaloids and Glycosides were screened according to the common phytochemical methods described previously (Harborne, 1998).

\section{In vitro antileishmanial activity studies}

L. amazonensis (MHOM/BR/73/M2269) amastigotes were isolated from active skin lesions from BALB/c mice as previously described (ArraisSilva et al., 2005). Primary mouse macrophages were obtained from normal BALB/c mice by peritoneal lavage, cultured in RPMI medium supplemented with antibiotics and $10 \%$ heat-inactivated fetal calf serum, on 24-well plates containing 13-mm diameter glass coverslips. Macrophages were exposed to $L$. amazonensis at an amastigote-macrophage ratio of 3:1 for $1 \mathrm{hr}$. After the exposure period, the cultures were washed to remove extracellular parasites and then incubated in the presence of different concentrations of the PPE at $37^{\circ} \mathrm{C}$ for $72 \mathrm{~h}$. For the evaluation of the PPE anti leishmanial activity, the percentage of infected macrophages and number of amastigotes per macrophage were determined in culture cells stained with Giemsa and examined microscopically at $\times 1,000$ magnification. Cell viability was determined by hemocytometer counts after staining with erythrosine B (Colhone et al., 2004). All experiments were repeated at least 3 times in triplicate wells, and the results are expressed as the mean $\pm S D$. Statistical analyses were performed using the 2-tailed Student's $t$-test and Origin 6.0 (OriginLab Corp., Northampton, Massachusetts). A $p<0.05$ value was considered to be significant (Arrais-Silva et al., 2005).

\section{RESULTS AND DISCUSSION}

Phytochemical screening of PPE has shown the presence of catechemical tannins, flavons, steroids, triterpenoids, flavonoid and xanthins (Table 1). Although the mechanism of action of these secondary metabolites has not been evaluated in the present study, however, some of these metabolites have been found to exert their anti-parasite effects by elevating cell oxidation or by inhibiting protein synthesis (Philipson \& Wright, 1990). The phytochemical investigation and isolation of various compounds from $P$. pubescens has led to the identification of xanthin and flavonoids with antibacterial, anticancer, antitumour, antitrypanosomal and antimalarial-like activities (Tran et al., 2003; Kamboj et al., 2010). 

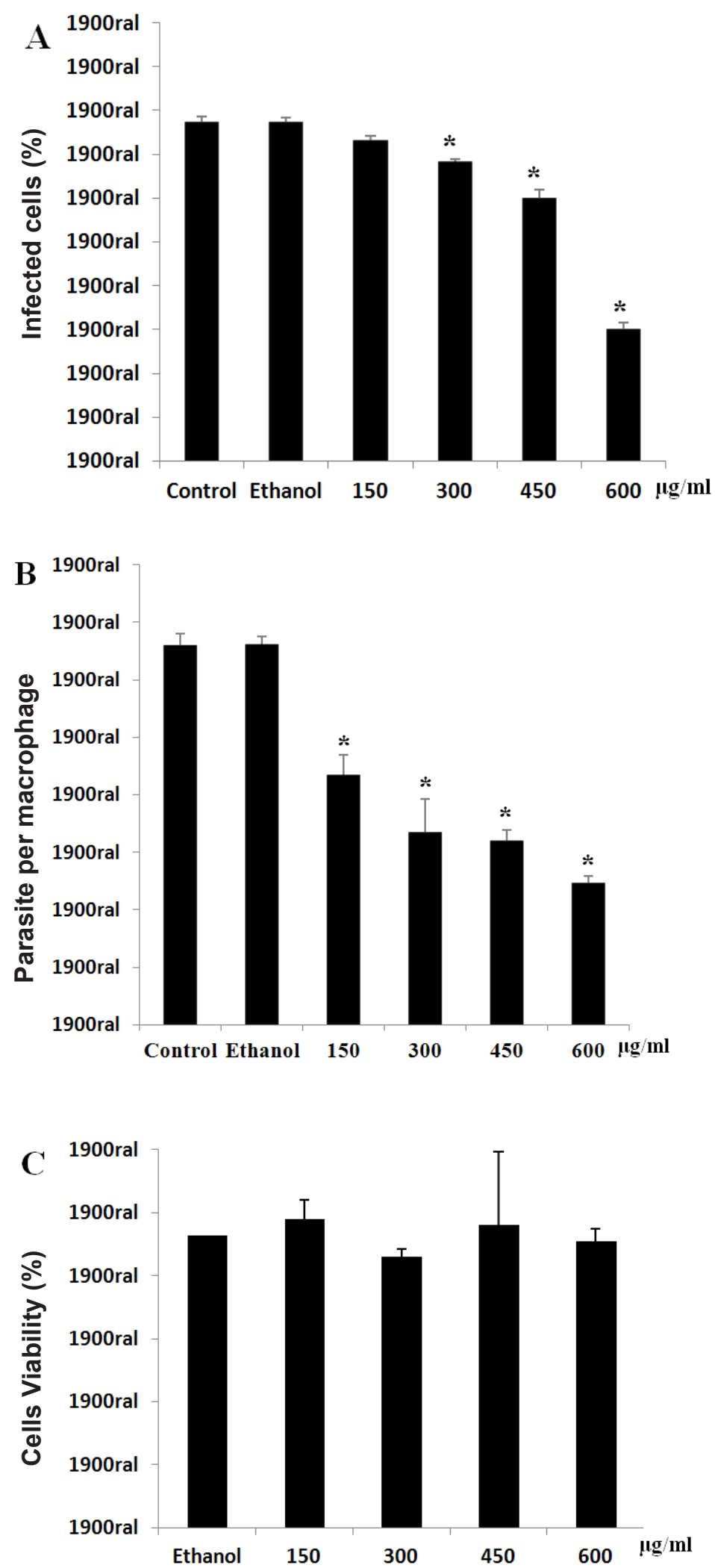

Figure 1. Effect of PPE on Leishmania amazonensis infection of murine peritoneal macrophages. Peritoneal macrophages of BALB/c were infected with $L$. amazonensis amastigotes for $1 \mathrm{hr}$. Cell cultures were washed and incubated under treatment conditions for $72 \mathrm{hr}$. The percentage of infected macrophages (A); the number of amastigotes per macrophage (B); and the percentage of viability cells by erythrosine-B staining (C). The results represent the mean \pm SD of 3 experiments. The significance of the difference between cell cultures in control and treated is indicated in the figure. ${ }^{*} p \leq 0.01$. 
Table 1. Preliminary phytochemical analysis of $P$. pudescens leaves extract

\begin{tabular}{l|l|l}
\hline \multicolumn{2}{l}{ Phytochemical test } & \multicolumn{2}{l}{ Leaves extract } \\
\hline Phenols & $\mathrm{FeCl}_{3}$ test & - \\
Pyrogallic Tannins & $\mathrm{FeCl}_{3}$ test & - \\
Catequic Tannins & $\mathrm{FeCl}_{3}$ test & ++ \\
Antocianins e antocianidins & $\mathrm{HCl}$ and $\mathrm{NaOH}$ test & - \\
Flavonoids & Flavonoids Shinoda test & + \\
Leucoanthocyanidins & $\mathrm{HCl}$ and NaOH test & + \\
Steroids & Lieberman-Burchard test & + \\
Pentacyclic Triterpenoids & Lieberman-Burchard test & + \\
Saponnins & Saponins Frothing test & + \\
\hline
\end{tabular}

+: present, -: absent

Here experiments were undertaken to study the possible effects of PPE on murine macrophages infected with amastigotes of $L$. amazonensis. PPE caused a concentration-dependent decreasing infected cell when compared with non-treated conditions. In fact, infected cell cultures untreated to PPE failed control parasite burden and exhibited $77.4 \%$ of infection, while infected macrophages exposed to $150,300,450$ and $600 \mu \mathrm{g} / \mathrm{ml}$ of PPE treatment had shown consistently decreasing of infected cells to $73.2,68.2,60$ and $30.1 \%$ respectively (Figure $1 \mathrm{~A}$ ).

There was also a significant reduction in the number of amastigotes per cell in PPE exposed macrophage cultures (1.2 amastigotes/cell at 600 $\mu \mathrm{g} / \mathrm{ml}$ extract concentration) when compared with control cell conditions (3.3 amastigotes/cell) (Figure 1B).

Exposure of infected macrophages cultures to PPE failed to affect cell viability or morphology as evaluated by erythrosine-B staining (Figure 1C) (Colhone et al., 2004). In fact, previous reports indicate save treatment with $P$. pudescens extracts components without side effects observed (Dutra et al., 2009).

To summarize, we have shown that Pterodon pubescens leaves extract induces macrophage resistance to $L$. amazonensis without side effects to host cells. However whether the effects of PPE on macrophages observed in vitro play a role in tissue damage occurring during the course of leishmaniasis is a question to be addressed.

\section{ACKNOWLEDGMENTS}

This work was supported by Fundação de Amparo à Pesquisa do Estado de Mato Grosso (grant number 568837/2008).

\section{REFERENCE}

ARRAIS-SILVA, W.W. et al. Effects of hyperbaric oxygen on Leishmania amazonensis promastigotes and amastigotes. Parasitology International, v. 54, n.14, p.1-7, 2005.

BERMAN, J. Visceral leishmaniasis in the New World \& África. Indian Journal Medical Research, v.123, n.3, p.289-94, 2006.

CARDOSO, C.C. et al. Suppression of T and B Cell Responses by Pterodon pubescenses Seeds Ethanolic Extract. Pakistan Journal of Biological Sciences, v.11, n.18, p.2308-2313, 2008.

COELHO, M.G.P.; SABINO, K.C.C.; DALMAU, S.R. Immunomodulatory effects of Sucupira (Pterodon pubescens) seed infusion on collagen-induced arthritis. Clinical and Experimental Rheumatology, v.22, n.2, p.213-8, 2004.

COLHONE, M. et al. Effect of hypoxia on macrophage infection by Leishmania amazonensis. Journal of Parasitology, v. 90, p. 510-515, 2004.

DUTRA, R.C. et al. Atividades antimicrobiana e leishmanicida das sementes de Pterodon emarginatus Vogel. Revista Brasileira de Farmacognosia, v.19, p.429-435, 2009.

GINSBURG, H.; DEHARO, E. A call sasfor using natural compounds in the development of new antimalarial treatment an introduction. Malaria Journal, v.10, p. S1, 2011.

GRIMALDI, G.; TESH, R.B. Leishmaniasis of the new world: Current concepts and implications for future research. Clinical Microbiology Reviews, v.6, p. 230-250, 1993.

HANDMAN, E. et al. Fishing for anti-leishmania drugs: principles and problems. Advances in Experimental Medicine and Biology, v. 625, p. 48-56, 2008.

HARBORNE, J.B. Phytochemical Methods: A guide to modern techniques of plant analysis. 3rd edn. Chap-man and Hall, New York, p. 1-150, 1998.

KAMBOJ, A.; SALUJA, A.K. Phytopharmacological review of Xanthium strumarium $L$. International Journal Green Pharmacology, v.4, p. 129-139, 2010.

LORENZI, H. Árvores Brasileiras: Manual de 
Identificação e Cultivo de Plantas Arbóreas Nativas do Brasil, v. 23 ed. São Paulo, 227, 2009.

MENNA-BARRETO, R.F.S. et al. Anti-Trypanosoma cruzi activity of Pterodon pubescens seed oil: geranylgeraniol as the major bioactive component. Parasitology Research, v.103, p. 111-117, 2008.

MISHRA, J.A.; SAXENA, A.; SINGH, S. Chemotherapy of leishmaniasis: past, present and future. Current Medical Chemical, v.14, p.1153-1169, 2007.

PEREIRA, M.F., et al. Terpenic subfraction of Pterodon pubescens induces apoptosis of K562 leukemic cells by modulating gene expression. Oncology Reports, v. 25, p. 215-221, 2011.

PHILIPSON, J.D.; WRIGHT, C.W. Antiprotozoal compund from plant source. Planta Medica, v. 57, p. 553-559, 1990.

TRAN, Q.L. et al. In vitro antiplasmodial activity of antimalarial medicinal plants used in Vietnamese traditional medicine. Journal of Ethnopharmacology, v.86, p. 249-252, 2003. 